Artur Znajomski Instytut Informacii Naukowej i Bibliotekoznawstwa Uniwersytet Marii Curie-Skłodowskiej w Lublinie e-mail: aznajomski@02.pl

\title{
Poczq̨tki bibliografii lokalnej w Polsce. Józef Ignacy Kraszewski i jego bibliografia druków wileńskich
}

STRESZCZENIE: Józef Ignacy Kraszewski, wybitny polski pisarz, publicysta i zarazem historyk, był także bibliografem. W 1842 r. ogłosił on Bibliografię druków wileńskich, opublikowaną w czwartym tomie jego monografii historycznej Wilno od początków jego do roku 1750. Jest to jedna z pierwszych na gruncie polskim bibliografii lokalnych podmiotowych. Zrodzona z pobudek patriotycznych i zainteresowań bibliograficznych autora, rejestruje druki tłoczone przez oficyny wileńskie w latach 1519-1799. Została stworzona w oparciu o szeroką bazę źródłową. W doborze materiału dąży do kompletności. Uwzględnia wszelkie druki wydane w Wilnie, niezależnie od ich treści i objętości. Zestawia publikacje ogłoszone w języku polskim, łacińskim, cerkiewnosłowiańskim, ruskim, litewskim i łotewskim, przy nieograniczonym zasięgu autorskim. Opis bibliograficzny, będący odzwierciedleniem karty tytułowej opisywanej publikacji, dopełniają bardzo często adnotacje księgoznawcze, treściowe i krytyczne. Bibliografia posiada układ chronologiczny. Materiał jest uporządkowany w kolejności dat wydania publikacji, a w obrębie poszczególnych lat opisy są podzielone na grupy językowe. Dzięki opracowaniu Bibliografii druków wileńskich Józef Ignacy Kraszewski zyskał trwałą pozycję w dziejach bibliografii polskiej.

SŁowA KLUCzowe: bibliografia lokalna, druki wileńskie 1519-1799, Kraszewski Józef Ignacy. 


\section{Wprowadzenie}

Sisy bibliograficzne o charakterze bibliografii lokalnej pojawiać się zaczęły w Europie w drugiej połowie XVI i XVII w. ${ }^{1}$ Głównie były to bibliografie podmiotowe rejestrujące twórczość autorów miejscowych lub wytwory typografii danego miasta. Polska ustępowała pod względem pierwszeństwa w tego rodzaju spisach tylko niewielu krajom europejskim. Bibliografia lokalna miała swoich reprezentantów już w XVII w., a w XVIII stuleciu ten typ bibliografii cieszył się dużym uznaniem. Powstawały przede wszystkim słowniki biobibliograficzne uczonych, literatów, duchownych poszczególnych miast. W opinii Cecylii Z. Gałczyńskiej palma pierwszeństwa powinna przypaść wydrukowanemu w $1671 \mathrm{r}$. dziełu Józefa Bartłomieja Zimorowicza Viri illustres civitatis Leopoliensis ${ }^{2}$.

Z czasem tworzenie bibliografii lokalnych różnych rodzajów znalazło wyraz w rozwijającym się od drugiej połowy XIX w. regionalizmie, zwłaszcza w Europie Zachodniej. Ten ruch społeczno-kulturalny, którego założeniem był zachowanie i kultywowanie odrębności kulturowych, rozwijał się szczególnie we Francji, Szwajcarii, Włoszech i Niemczech. W Polsce, w specyficznych warunkach rozbiorowych, rozwój bibliografii lokalnych stymulowany był przede wszystkim przez czynniki polityczne i narodowe ${ }^{3}$. W nurt patriotyczno-narodowy wpisuje się retrospektywna bibliografia druków wileńskich Józefa Ignacego Kraszewskiego. Autor zamieścił ją w czwartym tomie swojej monografii Wilno od początków jego do roku 1750, wydrukowanym w 1842 r. Praca powszechnie znana jest pod nazwą Bibliografia druków wileńskich $w$ Wilnie..., ale nie jest to jej oryginalny tytuł 4 .

1 T. Besterman, Les débuts de la bibliographie méthodique, Paris 1950, s. 70; L. Balsamo, Bibliography. History of tradition, Berkeley 1990, s. 75.

2 C. Z. Gałczyńska, Polska bibliografia terytorialna. Zarys dziejów, teoria i organizacja, „Zeszyty Naukowe Uniwersytetu Szczecińskiego Nr 67. Szczecińskie Prace Polonistyczne” 1991, nr 3, s. 169.

3 Zob. A. Matczuk, Rozwój metodyczny polskich bibliografii historycznych regionalnych, Lublin 1994, s. 13-15.

${ }^{4}$ Ponieważ tytuł Bibliografia nie ujawniał zwartości spisu, W. Hahn (autor Bibliografii bibliografii polskiej, Lwów 1921), chcąc zasygnalizować odbiorcy, że będzie miał do czynienia z wykazem druków wytłoczonych w Wilnie, uzupełnił tytuł informacją, iż 
Bibliografia Kraszewskiego nie była dotąd w kręgu zainteresowania badaczy, a wydaje się, że dla dziejów bibliografii polskiej przedstawia ona ciekawy materiał. Zestawienie druków wileńskich godne jest zwrócenia baczniejszej uwagi nie tylko ze względu na oryginalność i pomysłowość, ale i na sposób opracowania oraz metodykę.

Zanim przejdziemy do charakterystyki bibliografii Kraszewskiego, wypada wspomnieć o osobie jej inicjatora i twórcy oraz okolicznościach powstania spisu.

\section{Zainteresowania historyczne i bibliograficzne Józefa Ignacego Kraszewskiego}

Józef Ignacy Kraszewski urodził się w 1812 r. w Warszawie, pochodził z rodziny szlacheckiej z Podlasia ${ }^{5}$. Dzieciństwo spędził u dziadków Malskich na dworze w Romanowie. W 1822 r., mając dziewięć lat, rozpoczął naukę w szkole wydziałowej w Białej Podlaskiej, następnie przybył do Lublina do tutejszej szkoły wojewódzkiej, do której uczęszczał przez jeden rok szkolny (1826-1827). Studiował w Wilnie, lecz uniwersytetu nie ukończył, gdyż został aresztowany za udział w konspiracji przedpowstaniowej. Dzięki staraniom rodziny został zwolniony, ale od $1833 \mathrm{r}$. przebywał pod nadzorem policyjnym w Wilnie. W latach 1837-1853 gospodarował samodzielnie na wsi, prowadząc ożywioną działalność pisarską. Redagował również czasopismo naukowe „Athenaeum”, przy którym skupił znaczne grono badaczy i pisarzy. Po krótkim pobycie w Żytomierzu znalazł się w Warszawie, gdzie m.in. był redaktorem „Gazety Codziennej”. Po powstaniu styczniowym musiał opuścić Królestwo. Wyemigrował do Drezna i tam założył w 1868 r. drukarnię, której wyposażenie stało na wysokim poziomie. Drukował głównie dzieła polskie i dotyczące Polski, pamiętniki, listy, źródła historyczne. Kraszewski był artystą książki, dbał o jej szatę zewnętrzną. Był też wydawcą dwóch cza-

jest to Bibliografia druków wileńskich w Wilnie.... Sformułowanie to przyjęło się i upowszechniło.

${ }^{5}$ W. Danek, Kraszewski Józef Ignacy, [w:] Polski słownik biograficzny, t. 15, Kraków 1970, s. 221-229; T. Osiecka, Kraszewski Józef Ignacy, [w:] Słownik pracowników książki polskiej, pod red. I. Treichel, Warszawa 1972, s. 468-469. 
sopism „Notatki Drezdeńskie” i „Tydzień Polityczny, Naukowy, Literacki i Artystyczny". Na skutek poniesionych strat finansowych, w 1871 r. drukarnię sprzedał. W czasie wojny prusko-francuskiej w 1870 r. oskarżony został o zdradę stanu, szpiegostwo na rzecz Francji i uwięziony. Kraszewski, zwolniony z więzienia w ciężkim stanie, zmarł w 1887 r. w Genewie.

Zainteresowania historyczne Kraszewskiego narodziły się już we wczesnej młodości pod wpływem atmosfery panującej w jego domu rodzinnym. Ich rozwój nastąpił podczas kolejnych etapów edukacji odbytych w Białej Podlaskiej, Lublinie i Świsłoczy oraz w czasie studiów i w okresie przymusowego pobytu w Wilnie ${ }^{6}$. Twórczość naukowa autora Starej baśni kształtowała się w latach przejściowych w dziejach polskiej historiografii. Był to czas, kiedy, jak stwierdził Jerzy Maternicki:

[...] starły się dwie tendencje: bezkrytyczne zbieractwo pamiątek narodowych i dążenie do unaukowienia historii. Zbieractwo pamiątek narodowych zapoczątkowane zostało w pierwszych latach XIX w., a w okresie międzypowstaniowym znacznie się upowszechniło i przybrało na sile. Starano się ocalić od zapominania wszystko to, co dotyczyło dawnej Polski, jej ludzi, instytucji i zabytków. Pamięć o przeszłości, o Polsce niepodległej, była ważnym, jeżeli nie podstawowym, składnikiem ówczesnej świadomości narodowej Polaków. [...] Druga tendencja - dążenie do unaukowienia historiografii, miała już także swoją tradycję. Jej początek przypada na czasy Oświecenia i wiąże się z nazwiskiem Adama Naruszewicza. W pierwszych latach XIX w. duże zasługi na tym polu położyli historycy: Tadeusz Czacki, Jerzy Samuel Bandtkie, Ignacy Benedykt Rakowiecki i Hugo Kołłątaj, a w drugim i trzecim dziesięcioleciu Joachim Lelewel ${ }^{7}$.

Studia historyczne Kraszewskiego przypadają na lata, kiedy Lelewel, najwybitniejszy historyk polski doby romantyzmu, opuścił już Wilno, ale w mieście nad Wilią pozostali jego wychowankowie, pamiętający swojego mistrza oraz sprzyjająca badaniom historycznym atmosfera naukowa. Zapewne wpływ tego otoczenia odegrał ważną rolę w rozwoju s. 55-59.

${ }^{6}$ J. Jarowiecki, O powieści historycznej Józefa Ignacego Kraszewskiego, Kraków 1991,

7 J. Maternicki, Warszawskie środowisko historyczne 1832-1869, Warszawa 1970, s. $13-14$. 
zainteresowań historycznych Kraszewskiego. Skłaniał się on w kierunku źródłowych badań historycznych, a zwłaszcza pociągała go historia i kultura Wilna oraz Litwy.

Kraszewski penetrował biblioteki i archiwa, rozczytywał się w dziełach dotyczących dziejów Wilna, robiąc z nich notatki, konspekty, wycią$\mathrm{gi}^{8}$. W zbieraniu i poszukiwaniu materiału wspierał go między innymi Alojzy Osiński, profesor Gimnazjum Wołyńskiego, zarazem znakomity badacz piśmiennictwa polskiego. Zgromadzone w ciągu lat notatki i wiadomości bibliograficzne Kraszewski postanowił uporządkować i opracować monografię Wilna. W przedmowie do niej autor napisał:

Pierwszą myśl tego dzieła powziąłem przed dziesięciu jeszcze laty mieszkając w Wilnie, uderzony starożytnymi wspomnieniami miasta. Lecz wówczas nie pojmowałem jeszcze tej pracy tak obszernie jak dzisiaj; chciałem ją zamknąć w granicach szczupłych pod tytułem: Wspomnienia Wilna. [...] Potrzeba była przetrząsnąć częstokroć uparcie zamknięte archiwa klasztorne, biblioteki zakonne, przysłuchiwać się podaniom, potrzeba było prosić i nie doprosić się udzielenia wiadomości [...] spotykać z zazdrosnymi bibliografami, którzy pokazując z daleka co ciekawego, czem prędzej pod klucz chowali; trzeba było [...] bić się z zazdrością, głupstwem, bezczynną bojaźnią posiadaczy lub zawiadowców ksiąg i archiwów ${ }^{9}$.

Wśród motywów, które skłoniły Kraszewskiego do napisania monografii Wilno od poczq̨tków jego do roku 1750, dwa były najistotniejsze. Pierwszy to, jak stwierdził Feliks Kiryk, „[...] fascynacja Kraszewskiego malowniczym położeniem grodu na Wilią i jego niepowtarzalne zabytki architektury i sztuki, a także rola stołeczna i kulturalna Wilna w historii Litwy"10. Drugim było współzawodnictwo z Michałem Balińskim ${ }^{11}$, który

${ }^{8}$ S. Świerzewski, Kraszewski i książki, „Przegląd Biblioteczny” R. 33: 1965, z. 1, s. 32; J. Jarowiecki, dz. cyt, s. 59.

9 J. I. Kraszewski, Objaśnienie, [w]: Wilno od poczq̨tków jego do roku 1750, t. 1, Wilno 1840, s. XIV-XV.

${ }^{10}$ F. Kiryk, Józefa Ignacego Kraszewskiego historia miasta Wilna, [w:] Zbliżenia historycznoliterackie. Prace ofiarowane profesorowi Stanisławowi Burkotowi, pod red. T. Budrewicza, M. Busia i A. Gurbiela, Kraków 2003, s. 75.

11 J. I. Kraszewski, dz. cyt, s. XIV; zob. też P. Chmielowski, Józef Ignacy Kraszewski. Zarys historyczno-literacki postaci, Warszawa 1888, s. 100. 
w roku 1836 ogłosił swoją dwutomową Historię miasta Wilna ${ }^{12}$. Książka Balińskiego została doceniona przez Kraszewskiego. Zamieszczona w „Tygodniku Petersburskim” recenzja powieściopisarza była pełna pochwał, wskazywała wielkie znaczenie pracy Balińskiego w badaniu Litwy. Jednak entuzjastyczna ocena pracy zmieniła się w krytyczną po ukazaniu się drugiego tomu ${ }^{13}$.

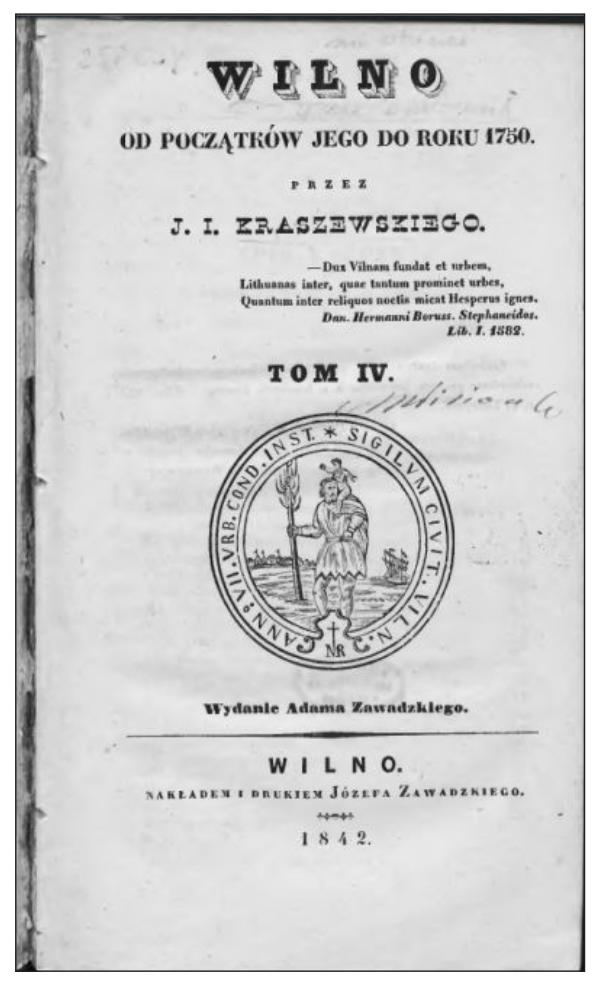

Ilustracja 1. Karta tytułowa czwartego tomu Wilno od poczq̨tków jego do roku 1750 (Wilno 1842) Źródło: Wilno od początków jego do roku 1750 [skan z Kujawsko-Pomorskiej Biblioteki Cyfrowej].

Tom pierwszy swojej monografii Kraszewski miał już gotowy z początkiem roku 1836, ale dopiero w 1838 r. zdołał go wydać w Wilnie, prawdopodobnie własnym nakładem, w drukarni Samuela Blumowi-

12 Zob. R. Naruniec, Michał Baliński jako mecenas polsko-litewskich więzi kulturowych, Warszawa 1995.

13 P. Zięba, Z dziejów polskiej konwencji wydawniczej. Edytorskie koncepcje i praktyka wydawnicza Józefa Ignacego Kraszewskiego, Kraków 2010, s. 181-183; R. Naruniec, dz. cyt., s. 138. 
cza $^{14}$. Spotkał się on z krytyką Ignacego Daniłowicza ${ }^{15}$. Pod wpływem tej krytyki Kraszewski przeredagował i poprawił cały tom, który po raz drugi został wydrukowany w $1840 \mathrm{r}$. Tom drugi ukazał się w tym samym roku, tom trzeci w 1841 r., a czwarty w roku 1842. Dzieło w całości wyszło nakładem księgarza i drukarza wileńskiego Adama Zawadzkiego. Monografia zebrała przychylne recenzje, jednak nie ustrzegła się też przed krytyką, dotyczącą niekompletności czy nieścisłości pewnych zawartych w niej informacji ${ }^{16}$.

\section{Geneza Bibliografii druków wileńskich}

W trakcie pracy nad monografią prawdopodobnie zrodził się pomysł zamieszczenia w niej bibliografii druków wileńskich wydanych przed XIX w. Można przypuszczać, że wiele przyczyn złożyło się na projekt opracowania bibliografii. Mnogość zebranych materiałów, dążenie do ratowania pamiątek narodowych, w tym opisywanie konkretnych druków oraz zainteresowanie bibliograficzne stanowiły na pewno zaczyn projektu. Sporządzoną bibliografią Kraszewski chciał też zapewne podbudować monografię i tym samym wzbudzić większą ciekawość.

Zainteresowanie bibliografią Kraszewski zawdzięczał niewątpliwie wyjątkowej atmosferze Wilna. W pierwszej połowie XIX stulecia w Wilnie prowadzone były liczne i ważne prace bibliograficzne. Według opinii Tadeusza Turkowskiego, skłaniał do tego:

${ }^{14}$ J. Fijałek, Opisy Wilna aż do połowy wieku XVII-go, „Ateneum Wileńskie” R. 1: 1923, nr 3-4, s. 320.

15 Zob. recenzję I. D[aniłowicz], „Tygodnik Petersburski” R. 10: 1839, nr 61, s. $352-$ -354; nr 62, s. 357-358; nr 63, s. 361-364; zob. też K. Sołtys, Józef Ignacy Kraszewski jako historyk. Naukowy fundament wykładu dziejów Litwy w monografii Wilna, Warszawa 2013, s. 49-51.

${ }_{16}$ Zob. recenzję [M. Homolnicki], Kilka uwag nad dziełem: Wilno od początków jego do roku 1750 przez J. I. Kraszewskiego, T. 1-2, Wilno 1840-1841, „Wizerunki i Roztrząsania Naukowe" t. 22: 1841, s. 5-221; t. 23: 1842, s. 5-207. 0 krytyce M. Homolnickiego napisał A. H. Kirkor, Wilno od początków jego do 1750 roku przez J. I. Kraszewskiego, [w:] Książka jubileuszowa dla uczczenia pięćdziesięcioletniej działalności literackiej J. I. Kraszewskiego, Warszawa 1880, s. 327-328 oraz K. Sołtys, dz. cyt., s. 51-55. 
[...] duch naukowy i wysoki poziom środowiska, równoczesny rozwój bibliografii na Zachodzie, wreszcie obudzone po rozbiorach zamiłowanie do rzeczy ojczystych, ruch w kierunku gromadzenia i inwentaryzacji kultury narodowej. Ówczesna wędrówka bibliotek, budzenie i tworzenie nowych zbiorów dawały sposobność do rejestracji i odkryćc ${ }^{17}$.

Wilno górowało nad innymi ośrodkami naukowymi tym, że zdołało wychować znaczny zespół bibliografów. Prace bibliograficzne szły w kilku kierunkach: od prób rejestracji całości piśmiennictwa, przez opracowywanie bibliografii dziedzinowych aż do tworzenia podstaw metodyki bibliografii. Warsztatem dla tych prac była zasobna Biblioteka Uniwersytetu Wileńskiego. Ruch bibliograficzny znalazł tu odpowiednią siłę wykonawczą w osobie księgarza i drukarza Józefa Zawadzkiego. Wychowany na wzorach niemieckich doceniał znaczenie bibliografii i miał w tym obszarze wiele zasług. Nie tylko bowiem wydawał wzorcowe katalogi własnej księgarni, ale także kosztowne i wymagające żmudnej pracy dzieła bibliograficzne ${ }^{18}$. To dzięki niemu Wilno stało się głównym ośrodkiem prac nad polską bibliografią narodową. W 1814 r. wydał Historię literatury polskiej wystawionq w spisie dzieł drukiem ogłoszonych Feliksa Bentkowskiego, uznawaną za pierwszą drukowaną polską bibliografię narodową. Nie jest rzeczą przypadku, że właśnie Wilno również dostarczyło najwięcej przyczynków do Historii literatury. Następnie z inicjatywy J. Zawadzkiego podjęte zostały prace nad drugim wydaniem dzieła F. Bentkowskiego - ostatecznie zakończyły się wydaniem trzech tomów Obrazu bibliograficzno-historycznego w opracowaniu Adama Benedykta Jochera.

Źródła związków Kraszewskiego z bibliografią tkwią w jego zainteresowaniach bibliofilskich, co znalazło bezpośrednie odbicie w zaangażowaniu się w prace nad powstającym wówczas Obrazem bibliograficzno-historycznym A. B. Jochera ${ }^{19}$. Kraszewski jako jeden z pierwszych

17 J. Czarnecki [T. Turkowski], Rzut oka na historię książki wileńskiej, „Przegląd Biblioteczny" R. 6: 1932, z. 1-2, s. 34.

18 R. Cybulski, Józef Zawadzki - księgarz, drukarz, wydawca, Wrocław 1972.

19 A. Kłossowski, Księgarze i bibliografia (2). (Dzieje wydawnicze „Obrazu bibliograficzno-historycznego” Adama Jochera na tle bibliograficznej działalności księgarzy europejskich), „Księgarz” R. 21: 1977, nr 1, s. 55-68. 
ofiarował swoją współpracę autorowi, nie szczędził rad i wskazówek oraz systematycznie dostarczał informacji bibliograficznych. Wydaje się, że współpraca z A. B. Jocherem i jego poglądy na bibliografię ${ }^{20}$ oddziałały silnie na przyszłego autora Bibliografii, bowiem zainteresowanie Kraszewskiego tą dziedziną ugruntowało się i nabrał zrozumienia dla jej zadań. Być może właśnie za namową Jochera postanowił, mimo braku doświadczenia i wiedzy bibliograficznej, sporządzić retrospektywne zestawienie druków wileńskich.

\section{Metoda opracowania Bibliografii druków wileńskich}

Bibliografia druków wileńskich powstała, podobnie jak całe dzieło, z myślą upamiętnienia historii Wilna, ukazania jego oblicza kulturalnego na tle historycznym. Celem bibliografii było opisanie i spisanie druków wytłoczonych przez oficyny wileńskie w ciągu trzech wieków - od XVI do XVIII.

Zestawienie druków wileńskich Kraszewski zatytułował Bibliografia. Podkreślić trzeba, że termin bibliografia w znaczeniu spisu bibliograficznego nie był w tym czasie używany; jedynym dziełem określanym tym terminem była Bibliographia Zalusciana (1763-1766) Jana D. Janockiego. Śledząc tytuły omawianych prac w Dziejach bibliografii w Polsce Józefa Korpały (Warszawa 1969), można przypuszczać, że Kraszewski był jednym z pierwszych w Polsce - jeśli nie pierwszym - który terminu bibliografia w formie spolszczonej użył jako tytułu dla swojego spisu. Dowodzi to, że w tym okresie określenie to zostało w pełni przyswojone przez środowisko wileńskie. Do jego spopularyzowania zapewne przyczyniła się poważnie rozprawa Joachima Lelewela zatytułowana Bibliograficznych ksiąg dwoje (Wilno 1823-1826). Dość powiedzieć, że w 1837 r. J. Zawadzki, drukarz wileński, chciał go wprowadzić do piśmiennictwa bibliograficznego, proponując dla drugiego wydania

${ }^{20}$ A. Jocher był głęboko przeświadczony, że pomniki piśmiennictwa narodu, jego skarby i chluba zarazem, świadczą o jego przeszłości, że przez zebranie i opisanie piśmiennictwa potrafi wytłumaczyć przeszłość narodową. Zob. J. Korpała, Dzieje bibliografii w Polsce, Warszawa 1969, s. 125. 
Historii literatury polskiej F. Bentkowskiego tytuł Bibliografia polska, ale musiał z tego zrezygnować na skutek stanowiska autora ${ }^{21}$.

Kraszewski zbierał materiał do całego dzieła, jak i bibliografii przez 10 lat. Zgromadził go, opierając się na zbiorach bibliotek wileńskich, jak również korzystał z prac o charakterze bibliograficznym i historycznym. Czerpał między innymi z: Historii drukarń w Królestwie Polskim i Wielkim Księstwie Litewskim (t. 1-3, Kraków 1826) Jerzego Samuela Bandtkiego, Historii literatury polskiej (t. 1-2, Warszawa 1814) Feliksa Bentkowskiego, Opytu ruskoj bibliografii (Petersburg 1825) Vasilija Sopikova, Dykcjonarza poetów polskich (Kraków 1820) Michała Hieronima Juszyńskiego, Herbarza polskiego (Lipsk 1839-1845) Kaspra Niesieckiego, Dziejów narodu litewskiego (t. 1-9, Wilno 1835-1841) Teodora Narbutta, Dykcjonarza uczonych Polaków (t. 1-3, Lwów 1833) Ignacego Chodynickiego. Kraszewski zwrócił się także do instytucji i osób prywatnych z prośbą o nadsyłanie materiałów do monografii. Apel nie odniósł skutku. Tylko dwie osoby bezinteresownie udostępniły mu niektóre materiały: profesor Iwan Łobojko, emerytowany profesor literatury rosyjskiej na Uniwersytecie Wileńskim oraz prałat Mamert Herbutt ${ }^{22}$.

Podejmując prace nad zestawieniem Kraszewski musiał rozwiązać wiele problemów pracy bibliograficznej, słowem - określić założenia metodyczne spisu. Stosunkowo najwięcej skorzystał przy sporządzaniu swojej bibliografii na współpracy z A. B. Jocherem. Wzory mógł znaleźć jedynie w retrospektywnych bibliografiach narodowych polskich i obcych. Toteż w koncepcji publikacji wzorował się na takich autorytetach, jak: F. Bentkowski, A. B. Jocher i Vasilij Sopikov.

Pierwszym warunkiem, jaki Kraszewski stawiał Bibliografii, było dążenie do kompletności. Jej zasięgiem obejmował wszystkie druki, choćby najmniejszej objętości i znaczenia, „[...] nie pomijając nawet panegiryków, mów, powinszowań, świstów najmniejszych"23. Wynika z tego, że miał świadomość, iż nawet pozornie bezwartościowe, drobne druki, mogą rzucić nowe światło na życie kulturalne miasta. Dążenie do kompletności, tak silnie akcentowane przez Kraszewskiego, jest do dzisiaj

${ }^{21}$ Materiały do dziejów literatury i oświaty na Litwie i Rusi. Z archiwum drukarni Józefa Zawadzkiego z lat 1805-1865, zebr. T. Turkowski, t. 2, Wilno 1937, s. 252, 264.

22 A. H. Kirkor, dz. cyt., s. 328.

${ }^{23}$ J. I. Kraszewski, Kronika bibliograficzna, [w:] Wilno od początków jego do roku 1750, t. 4, Wilno 1842, s. 113. 
postulatem aktualnym w bibliografii lokalnej podmiotowej. Autor zdawał sobie sprawę, że bibliografia nie odnotowuje wszystkich druków, jakie powinny się w niej znaleźć, o czym napisał w przedmowie. Wynikało to z przyczyn niezależnych od autora. W $1835 \mathrm{r}$. Kraszewski wyjechał z Wilna i zamieszkał w majątku ojca w Dołhe, a następnie w Gródku. Oddalenie od Wilna i bibliotek oraz liczne kłopoty z pozyskiwaniem nowych materiałów odbiło się niekorzystnie na kompletności bibliografii.

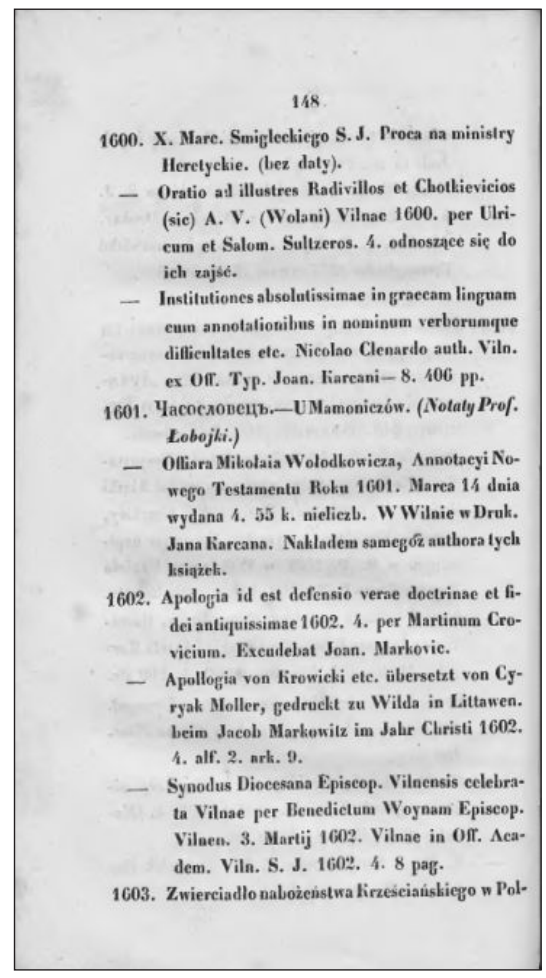

Ilustracja 2. Fragment Bibliografii J. I. Kraszewskiego

Źródło: Wilno od poczq̨tków jego do roku 1750, s. 148 [skan z Kujawsko-Pomorskiej Biblioteki Cyfrowej].

Bibliografia rejestruje druki wydane w Wilnie, bez względu na ich treść, język i narodowość autora. Odnotowuje druki w języku polskim, łacińskim, cerkiewnosłowiańskim, ruskim, litewskim, łotewskim, wydrukowane do roku 1799. Zasięgiem swoim obejmuje wszystkie materiały drukowane: książki, kalendarze, druki ulotne. Rejestrując w Bibliografii zasadniczo dzieła drukowane, czasem odstępował Kraszewski od tej zasady i opisywał w oddzielnych pozycjach prace rękopiśmienne napisane w Wilnie. Niekiedy również podawał informacje z zakresu bibliografii 
przedmiotowej, podając dzieła wydrukowane poza Wilnem związane osobą lub treścią z miastem.

Charakterystyczną cechą Bibliografii jest to, że górna granica zasięgu chronologicznego (1799) nie odpowiada ramom chronologicznym monografii (1750). Okoliczność tę można tłumaczyć tym, że Kraszewski pierwotnie nie myślał o zamieszczeniu bibliografii, potem postanowił rozszerzyć jej ramy tak, by obejmowała swym zasięgiem również druki wydane do końca XVIII w.

Bibliografia ma układ chronologiczny, materiał ułożony jest w kolejności czasu wydania publikacji. Na końcu każdego wieku umieszczany jest spis tych dzieł, których daty wydania nie ustalono. Sądzić należy, że wybór układu był wyrazem świadomej intencji bibliografa, który pozwalał na prześledzenie rozwoju dorobku wydawniczego Wilna, jego natężenia w poszczególnych latach.

W obrębie lat Kraszewski wprowadził podział na grupy językowe. Najpierw wykazywane są pozycje w językach: cerkiewnosłowiańskim, litewskim, ruskim, łotewskim, potem w języku polskim, a na końcu po łacinie. $W$ ramach języka pozycje szeregowane są różnie, ale z tendencją zachowania kolejności rzeczowej lub alfabetycznej. Układ chronologiczny miał też swoje wady, rozpraszał wydania, przekłady tego samego dzieła, zacierał obraz ich poczytności. Odnotować trzeba dostrzegalne zainteresowanie Kraszewskiego odsyłaczami łączącymi kolejne wydania i przeróbki, aczkolwiek stosowane sporadycznie i ograniczone tylko do kilku pozycji. Przy braku numeracji odsyłacz kieruje do roku druku innych wydań (s. 346). Kazanie Skargi o siedmiu Sakramentach przedruk w Wil. Fol Typ. Acad. (Patrz 1737); (s. 342) Nauka o krasomówstwie z Ksiąg Cycerona przez X. Józefa Boreykę etc. Wiln. Dr. AK. Wydan 2-ie (Patrz 1763). Patrząc na praktyczną realizację układu należy stwierdzić, że jest to przykład trafnych rozwiązań, odpowiadających nawet wymaganiom współczesnej metodyki bibliograficznej.

Z danych, które udało się Kraszewskiemu zebrać wynika, iż w ciągu trzech wieków ukazały się 1402 druki, w tym w XVI - 140, XVII - 429 i XVIII - 833. Zestawienie repertuaru wydawniczego odzwierciedlało zwiększające się zapotrzebowanie wilnian na książki i inne materiały drukowane. Obrazowało wielkość produkcji wydawniczej w kolejnych latach, a w konsekwencji rozwój kulturalno-umysłowy Wilna. Bibliografia Kraszewskiego pokazuje wielkie znaczenie Wilna w dziejach kultury 
narodowej. Potwierdza, że choć Wilno było kolebką książki łotewskiej, litewskiej i ruskiej, to istotną treścią życia umysłowego miasta była kultura polska, zwłaszcza XVII i XVIII w.

Najwcześniejszą datą cytowaną w Bibliografii jest rok 1519, od którego rozpoczyna się zestawienie druków. Pod tą datą wymieniono pozycję Apostoł w Wilnie, wydrukowaną w języku starocerkiewnym, z zastrzeżeniem, że prawdopodobnie nie ukazała się w Wilnie, lecz w Pradze. Cztery następne pozycje z roku 1522 i 1525 to także druki w języku starocerkiewnym. Pod datą 1533 Bibliografia cytuje pierwszy druk wileński przetłumaczony z łaciny na język polski: Księgi o wychowaniu i ćwiczeniu Reinharda Lorichiusa, natomiast pod datą roczną 1576 odnotowane są dwie oryginalne prace w języku polskim: Psałterz słowiański i O miłościwym lecie. Górną granicą Bibliografii jest rok 1799. Jak widać, Kraszewski liczył stulecia od roku 100 zamiast od 101, a więc spis druków wieku XVI kończy się na 1599, wiek XVII obejmuje lata 1600-1699, wiek XVIII - 1700-179924.

Opis bibliograficzny zastosowany przez Kraszewskiego zawiera w zasadzie wierną kopię karty tytułowej danego druku ze wszystkimi szczegółami, zwłaszcza w przypadkach druków nieznanych bibliografom lub kiedy konieczne to było dla wyjaśnienia jakiejś sprawy lub przytoczenia daty. Ciekawe, że w odpisie tytulatury druków rzadkich dokładność Kraszewskiego jest widoczna niekiedy do tego stopnia, że dawał opis karty tytułowej z oznaczeniem kreską pionową podziału na wiersze (s. 122). Zabieg ten był w owych czasach raczej zjawiskiem niespotykanym $^{25}$.

Dokładność i szczegółowość opisu nie jest we wszystkich pozycjach jednakowa, szczególnie zapisy czerpane z „drugiej ręki” wykazują wiele niedokładności. Niektóre opisy wyrażone są w mocno skróconej formie, ograniczone do autora, tytułu, miejsca wydania lub formatu. Tytuły druków dość często są skracane, a część opuszczona jest sygnalizowana

${ }^{24}$ Ten sposób liczenia stulecia w XIX w. nie był zjawiskiem sporadycznym. Podobnie postąpił K. Estreicher w Bibliografii polskiej; zob. M. Dembowska, Metoda Bibliografii polskiej Karola Estreichera, Warszawa 2001, s. 33.

${ }_{25}$ Tę stronę opisu bibliograficznego rozwinął dopiero Teodor Wierzbowski w dziele Bibliographia Polonica XV ac XVI saeculorum (Vol. 1-3, Varsovia 1889-1894), zob. Z. Gaca-Dąbrowska, Teodor Wierzbowski jako bibliograf, „Roczniki Biblioteczne” R. 18: 1974, z. 3-4, s. 743. 
skrótem „etc.” lub wykropkowywana. Skracane są również wyrazy w tytule, pomijane godności osobiste, jak tytuły, przydomki czy pełnione funkcje. Identyfikację druków utrudnia niejednokrotnie zbyt swobodne zmienianie tytułów. Podawane są one w brzmieniu oryginalnym i odpowiednimi czcionkami.

$\mathrm{Z}$ adresu wydawniczego przytaczał Kraszewski miejsce i rok druku, choć nie był w tym konsekwentny. W przypadku nieoznaczonego na karcie tytułowej miejsca wydania zaznaczał: „Bez miejsca druku”, „Bez oznaczenia miejsca druku” lub podawał skrót: „b. m. druku; (b. r.)”. Jeżeli miejsce druku było niepewne stawiał przy nim znak zapytania lub pisał „zapewne w Wilnie”. Data wydania wyrażona jest cyframi rzymskimi lub arabskimi.

Uwzględnianie drukarni, z której wyszło dzieło, było raczej stałą zasadą w Bibliografii. Podobnie jak oznaczenie formatu druku. Format wyrażony jest za pomocą symboli cyfrowych, czasem z różnymi przydawkami, np. „8 minori”. Przy drukach, wyjąwszy drobne druki okolicznościowe, Kraszewski podawał strony bądź karty liczbowane i nieliczbowane, czasem sygnatury arkuszowe, natomiast w wydawnictwach wielotomowych wymieniał tomy lub części. Na objętość dzieła autor zwracał szczególną uwagę, zaznaczając, jeśli było to konieczne, osobno paginację wstępu, tekstu i indeksów. Było to całkowitą nowością w bibliografiach. Przy opisach branych z drugiej ręki wskazywał Kraszewski zawsze na opis źródła, podając nazwę autora, czasem też tytuł w skrócie oraz odpowiednią stronę (np. „Janociana III 345”). W nawiasie podawał nazwisko autora druku anonimowego, jeśli było mu ono skądinąd znane. Również inne elementy wprowadzane do opisów spoza tytulatury często ujmował w nawias okrągły. 0 skrupulatności Kraszewskiego świadczą poprawki błędów występujących w opisach dzieł w innych bibliografiach. Przy informacjach, które uważał za nieprawdziwe lub błędne, zamieszczał zwrot „sic” (np. „O biesiadzie karczemnej i skrzypkach. Wilno 1619 przez Walentego Bartochowicza (sic) (Siarczyński) zapewne Wal. Bartoszewskiego S.J.?"). Najczęściej korygowane są błędy w nazwiskach autorów, miejscu i roku wydania, nazwiskach drukarzy. Nie znaczy to, że Bibliografia była pozbawiona błędów. Jeżeli miał on pewne wątpliwości co do informacji podanych przez siebie, wyrażał je w uwadze na końcu opisu, często stawiając także znak zapytania. 
Prócz opisów pełnych Kraszewski stosował opisy skrócone. Występują one przy wykazywaniu prac danego autora; zamiast powtórzenia nazwiska autora zastosował skrót „Tegoż”.

Kraszewski nie poprzestawał na opisie fizycznym druku, lecz podawał wiele cennych i interesujących informacji o charakterze księgoznawczym i treściowym. Dotyczą one bądź wydawniczo-formalnej strony bądź ich treści. Autor podał obszerniejsze adnotacje o treści dzieł rzadkich, podobnie jak to uczynił A. B. Jocher. Programowo adnotacje występują przy drukach z XVI i XVII w., znacznie rzadziej z XVIII w.

Sporo uwagi poświęcił Kraszewski kwestii wątpliwego lub błędnego autorstwa. Czasem ograniczał się do lakonicznej notatki wymieniającej nazwisko właściwe autora, ale nierzadko podał też uzasadnienie swego twierdzenia, powołując się na odpowiednie źródła. Adnotacje zawierają informacje o kolejnych wydaniach, przedrukach tego samego dzieła wydrukowanych poza Wilnem, a także inne dane o druku lub jego autorze. W licznych przypadkach podają wiadomości o zasługujących na podkreślenie materialnych cechach dokumentu np. o papierze („na przepięknym papierze”), rodzaju druku (np. „druk gocki”, „druk gocki piękny”), o herbach, ornamentach (np. „Tytuł w obwódce”), formie językowej i piśmienniczej (np. „wierszem”), o układzie tekstu, o częściach składowych książki (dedykacje, przedmowy, indeksy, zakończenie, errata). Informują o przedrukach i przekładach dzieł, stanowiących część jakiejś całości wydawniczej (s. 137: „Przedrukowano w zbiorze Petarum polonorum Carmina pastoralna - 1779. Altenburgii. W. Trębicki”), (s. 118: „Toż dzieło przedrukowane przy kazaniach przygodnych u Andrzeja Piotrkowczyka. Krak. 1610").

$\mathrm{Z}$ adnotacji dowiadujemy się również o rzadkości dzieła (np. rzadkie, bardzo rzadkie). Można sądzić, że manierę tę Kraszewski przejął chyba od V. Sopikova, który w swojej bibliografii umieszczał właśnie tego typu informacje. Przy unikalnych egzemplarzach podawał nazwę biblioteki.

Informując o treści dzieła, Kraszewski postępował w różny sposób. Nieraz podawał krótko jego temat (np. „Polemika religijna”, „Pismo złośliwe przeciw Tatarom”), czasem zamieszczał spis treści, zwracał uwagę czytelnika na jakąś część pracy, zawierającą ciekawe szczegóły. Spotykamy też informacje pochodzące z dedykacji, z jakiegoś fragmentu dzieła. 
Adnotacje podają nazwiska osób związanych z danym drukiem, wymieniają adresatów dedykacji, osoby, do których odnosi się treść książki.

W adnotacjach widać wyraźnie krytyczny, oceniający stosunek do omawianego dzieła. Kraszewski niejednokrotnie wypowiadał sąd o ich wartości. Opinia ta dotyczyła głównie zewnętrznej postaci publikacji, formy językowej, rzadko wartości merytorycznej. Oceny formułowane są w sposób krótki, np. „Wiersz niezły wcale, dziełko bardzo dziś rzadkie" (Wybranych zdań Teognidesa Megareńczyka przez Stanisława Kółkowskiego Jaćwieża, 1502), „Styl czysty i dobry” (O jednej osobie w używaniu Sakramentu, 1589), „Na odwrocie piękny cięty herb” (Wiosna niezwiędłych w niebie pociech, 1755).

Zestawienie druków wileńskich posiada przejrzystą kompozycję graficzną. Głównym elementem szeregującym pozycje bibliograficzne jest rok wydania umieszczony na lewym marginesie. Data roczna występuje tylko przy pierwszej pozycji, dalej zastępuje ją kreska pozioma. Jeśli opis dzieła z danego roku znajduje się na następnej stronie, to powtórzony jest rok wydania. Druki bez ujawnionej daty wydania oddzielone są kreską poziomą. Źródła, na które powołuje się autor, wyróżnione są kursywą. Adnotacje umieszczane są bezpośrednio po opisie i składane tym samym co opis stopniem czcionki. Sprawia to, że są mało przejrzyste i czytelne. Pozycje nie są numerowane.

Zestawienie Kraszewskiego nie posiada indeksu, co automatycznie obniża jego sprawność informacyjną. Odczuwa się zwłaszcza brak szczegółowej informacji dotyczącej autorów. Nie ma również przedmowy informującej o sposobie gromadzenia materiałów, wykorzystanych źródłach bibliograficznych oraz metodzie opracowania bibliografii.

Oceniając Bibliografię w stosunku do ówczesnego stanu metodyki bibliograficznej, można stwierdzić, że praca pod względem koncepcji i metody opracowania jest na dobrym poziomie. Trzeba podkreślić nowatorskie podejście Kraszewskiego do zasad opisu starych druków i zadań bibliografii. Całkowitą nowością w ówczesnych bibliografiach było podawanie, co prawda sporadycznie, elementów karty tytułowej w jej oryginalnym układzie z zastosowaniem kreski pionowej na oznaczenie podziału na wiersze oraz objętości dla części składowych dzieła, co służyć miało identyfikacji wydań. Świadczy to o wysokim poziomie wiedzy bibliograficznej Kraszewskiego. 
Opinie współczesnych na temat Bibliografii Kraszewskiego bywały różne, ale na ogół przychylne. Zdaniem Karola Estreichera, autor wykazał się wyjątkową drobiazgowością przy tworzeniu wykazu²6. Późniejsze oceny były bardziej krytyczne. Niezbyt pochlebnie o Bibliografii wyrażał się Michał Brensztejn, uważając, że zestawienie jest „[...] bardzo niekompletne, tylko w pewnym stopniu składające się na przybliżony obraz produkcji typograficznej wileńskiej przed wiekiem XIX-tym"27. Z kolei Stefan Świerzewski zarzucił Kraszewskiemu bezkrytyczne przejmowanie informacji z różnych wydawnictw, przez co zestawienie posiada wiele błędów i nieścisłości ${ }^{28}$.

Bibliografia Kraszewskiego jest bez wątpienia pierwszą poważniejszą pracą bibliograficzną o charakterze lokalnym na ziemiach polskich, pierwszą bibliografią lokalną podmiotową, obejmującą druki tylko jednej miejscowości, co czyni Józefa Ignacego Kraszewskiego pionierem bibliografii lokalnej w Polsce. Wprawdzie poprzedził go Antoni Moszyński, który w 1841 r. ogłosił Bibliologię wileńskq w „Tygodniku Petersburskim", rejestrującą nowe druki wileńskie ${ }^{29}$. Jest to jednak bardziej omówienie bibliograficzne niż bibliografia w ścisłym tego słowa znaczeniu. Kraszewski natomiast badał i opisywał druki zgodnie z obowiązującymi wówczas metodami i standardami. Tym zyskał sobie niekwestionowaną pozycję wśród współczesnych i potomnych w dziejach polskiej bibliografii.

Zestawienie druków wileńskich, choć dalekie od kompletności, w ówczesnym okresie badań historycznych było po prostu ewenementem, gdyż odsłaniało bogactwo dorobku wydawniczego jednego tylko miasta. Znaczenie Bibliografii Kraszewskiego polega na tym, że od niej rozpoczyna się cały ciąg polskich bibliografii lokalnych ${ }^{30}$. Zasługa Kra-

${ }^{26}$ K. Estreicher, Bibliografia polska XIX-go stulecia, „Biblioteka Warszawska” t. 3: 1862, s. 341.

27 M. Brensztejn, Tradycje bibliografii dzielnicowej czyli regionalnej wileńskiej, „Przegląd Biblioteczny" R. 3: 1929, z. 1, s. 28.

${ }^{28}$ S. Świerzewski, dz. cyt., s. 28.

29 A. Moszyński, Bibliologia wileńska, „Tygodnik Petersburski” R. 12: 1841, nr 2, s. 11-13; nr 3, s. 16.

${ }^{30}$ K. Sienkiewicz, Bibliografia krzemieniecka 1857-1858, [w:] Biesiada krzemieniecka w Paryżu dnia 5 października 1858, Paryż 1859, s. 20-46; M. Zieleniewski, Bibliografia Krynicy, Kraków 1881; M. Baruch, Spis bibliograficzny druków łódzkich, Łódź 1896; T. Janiszewski, Bibliografia zakopiańska, Kraków 1899. 
szewskiego jest tym większa, że zapoczątkował on tradycję rejestrowania i dokumentowania dorobku wydawniczego Wilna, kultywowaną nieprzerwanie do roku $1928^{31}$.

Ceniona ze względu na bogactwo materiałów, w dalszym rozwoju bibliografii polskiej miała znaczenie także jako źródło informacji bibliograficznej. Sam Karol Estreicher wykorzystał bibliografię jako źródło wiedzy w Bibliografii polskiej.

\section{Bibliografia}

Balsamo Luigi, Bibliography. History of tradition, Berkeley 1990.

Baruch Maksymilian, Spis bibliograficzny druków łódzkich, Łódź 1896.

Besterman Theodore, Les débuts de la bibliographie méthodique, Paris 1950.

B[rensztejn] M[ichał], Druki polskie wydane w Wilnie [w latach 1911-1913 wraz z dopełnieniami z lat poprzednich], „Rocznik Towarzystwa Przyjaciół Nauk w Wilnie" t. 5: 1911-1914, s. 401-422.

Brensztejn Michał, Tradycje bibliografii dzielnicowej czyli regionalnej wileńskiej, „Przegląd Biblioteczny” R. 3: 1929, z. 1, s. 28-30.

Chmielowski Piotr, Józef Ignacy Kraszewski. Zarys historyczno-literacki postaci, Warszawa 1888.

Cybulski Radosław, Józef Zawadzki - księgarz, drukarz, wydawca, Wrocław 1972.

Czarkowski Ludwik, Spis druków polskich wydanych w Wilnie od r. 1900 [do 1910 włącznie], „Rocznik Towarzystwa Przyjaciół Nauk w Wilnie” t. 1-4: 1907-1910.

Czarnecki Jerzy [Turkowski Tadeusz], Rzut oka na historię książki wileńskiej, „Przegląd Biblioteczny” R. 6: 1932, z. 1-2, s. 1-41.

Danek Wincenty, Kraszewski Józef Ignacy, [w:] Polski słownik biograficzny, t. 15, Kraków 1970, s. 221-229.

31 A. H. Kirkor, Vilenskaja bibliografija za 1852 god., [w:] Pamiatnaja knižka vilenskoj gubernii na 1853 god, Č. 2, Vilno 1853, s. 121-127; L. Czarkowski, Spis druków polskich wydanych w Wilnie od r. 1900 [do 1910 włącznie], , Rocznik Towarzystwa Przyjaciół Nauk w Wilnie" t. 1-4: 1907-1910; M. Brensztejn, Druki polskie wydane w Wilnie [w latach 1911-1913 wraz z dopełnieniami z lat poprzednich], „Rocznik Towarzystwa Przyjaciół Nauk w Wilnie" t. 5: 1911-1914, s. 401-422. 
D[aniłowicz] I[gnacy], [Rec.], Kraszewski Józef Ignacy, Wilno od początków jego do roku 1750, t. 1, Wilno 1839, „Tygodnik Petersburski” R. 10: 1839, nr 61, s. 352-354; nr 62, s. 357-358; nr 63, s. 361-364.

Dembowska Maria, Metoda Bibliografii polskiej Karola Estreichera, Warszawa 2001.

Estreicher Karol, Bibliografia polska XIX-go stulecia, „Biblioteka Warszawska” t. 3: 1862 , s. $324-348,507-550$.

Fijałek Jan, Opisy Wilna aż do połowy wieku XVII-go, „Ateneum Wileńskie” R. 1: 1923, nr 3-4, s. 313-336.

Gaca-Dąbrowska Zofia, Teodor Wierzbowski jako bibliograf, „Roczniki Biblioteczne" R. 18: 1974, z. 3-4, s. 719-771.

Gałczyńska Cecylia Zofia, Polska bibliografia terytorialna. Zarys dziejów, teoria i organizacja, „Zeszyty Naukowe Uniwersytetu Szczecińskiego Nr 67. Szczecińskie Prace Polonistyczne" 1991, nr 3, s. 169-183.

[Homolnicki Michał], [Rec.], Kilka uwag nad dziełem: Wilno od początków jego do roku 1750 przez J. I. Kraszewskiego, t. 1-2, Wilno 1840-1841, „Wizerunki i Roztrząsania Naukowe” t. 22: 1841, s. 5-221; t. 23: 1842, s. 5-207.

Janiszewski Tomasz, Bibliografia zakopiańska, Kraków 1899.

Jarowiecki Jerzy, O powieści historycznej Józefa Ignacego Kraszewskiego, Kraków 1991.

Kirkor Adam Honory, Vilenskaja bibliografija za 1852 god., [w:] Pamiatnaja knižka Vilen'skoj gubernii na 1853 god, Č. 2, Vilno 1853, s. 121-127.

Kirkor Adam Honory, Wilno od początków jego do 1750 roku przez J. I. Kraszewskiego, [w:] Książka jubileuszowa dla uczczenia pięćdziesięcioletniej działalności literackiej J. I. Kraszewskiego, Warszawa 1880, s. 327-328.

Kiryk Feliks, Józefa Ignacego Kraszewskiego historia miasta Wilna, [w:] Zbliżenia historycznoliterackie. Prace ofiarowane profesorowi Stanisławowi Burkotowi, pod red. Tadeusza Budrewicza, Marka Busia i Andrzeja Gurbiela, Kraków 2003, s. 74-79.

Kłossowski Andrzej, Księgarze i bibliografia (2). (Dzieje wydawnicze „Obrazu bibliograficzno-historycznego" Adama Jochera na tle bibliograficznej działalności księgarzy europejskich), „Księgarz” R. 21: 1977, nr 1, s. 55-67.

Korpała Józef, Dzieje bibliografii w Polsce, Warszawa 1969.

Kraszewski Józef Ignacy, Bibliografia, [w:] Wilno od początków jego do roku 1750, t. 4, Wilno 1842, s. 315-365.

Kraszewski Józef Ignacy, Kronika bibliograficzna, [w:] Wilno od początków jego do roku 1750, t. 4, Wilno 1842, s. 113. 
Kraszewski Józef Ignacy, Objaśnienie, [w]: Wilno od początków jego do roku 1750, t. 1, Wilno 1840, s. XIII-XVIII.

Matczuk Alicja, Rozwój metodyczny polskich bibliografii historycznych regionalnych, Lublin 1994.

Materiały do dziejów literatury i oświaty na Litwie i Rusi. Z archiwum drukarni Józefa Zawadzkiego z lat 1805-1865, zebr. Tadeusz Turkowski, t. 2, Wilno 1937.

Maternicki Jerzy, Warszawskie środowisko historyczne 1832-1869, Warszawa 1970.

Moszyński Antoni, Bibliologia wileńska, „Tygodnik Petersburski” R. 12: 1841, nr 2, s. 11-13; nr 3, s. 16.

Naruniec Romuald, Michał Baliński jako mecenas polsko-litewskich więzi kulturowych, Warszawa 1995.

Osiecka Teresa, Kraszewski Józef Ignacy, [w:] Słownik pracowników książki polskiej, pod red. Ireny Treichel, Warszawa 1972, s. 468-469.

Sienkiewicz Karol, Bibliografia krzemieniecka 1857-1858, [w:] Biesiada krzemieniecka w Paryżu dnia 5 października 1858, Paryż 1859, s. 20-46.

Sołtys Karolina, Józef Ignacy Kraszewski jako historyk. Naukowy fundament wykładu dziejów Litwy w monografii Wilna, Warszawa 2013.

Świerzewski Stefan, Kraszewski i książki, „Przegląd Biblioteczny” R. 33: 1965, z. 1, s. 26-35.

Zieleniewski Michał, Bibliografia Krynicy, Kraków 1881.

Zięba Paweł, Z dziejów polskiej konwencji wydawniczej. Edytorskie koncepcje i praktyka wydawnicza Józefa Ignacego Kraszewskiego, Kraków 2010.

\section{The Rise of Polish local bibliography. Józef Ignacy Kraszewski and his bibliography of Vilnius prints}

ABSTRACT: Józef Ignacy Kraszewski, an outstanding Polish writer, publicist and historian, was also a bibliographer. In 1842, as part of the 4th volume of his historical monograph Vilnius: from its very beginning to 1750 , he published the Bibliography of Vilnius prints. It was one of the first local subject bibliographies in Poland. Compiled in close connection with Kraszewski's patriotic postulates and bibliographic interests, this bibliography registered all works published by Vilnius printing houses in 1519-1799. The bibliography comprises broad range 
of sources aiming at completeness with regard to material selection. All types of works are included, e.g. texts in Polish, Latin, Church Slavonic, Ruthenian, Lithuanian and Latvian, with unlimited range of authors. Bibliographic record not only reflects the title page of a publication, but also it is often supplemented with bibliographic content or critical annotations. The bibliography is arranged chronologically, in line with the date of publishing; within respective dates of publishing titles are grouped accordingly to the language of publication. Owing to compiling the Bibliography of Vilnius prints, Kraszewski acquired a solid position in the history of Polish bibliography.

KEYwordS: Kraszewski Józef Ignacy, local bibliography, Vilnius prints 1519$-1799$. 
